\title{
Research
}

\section{Outcomes of State- vs. Community-Based Mangrove Management in Southern Thailand}

\author{
Chanyut Sudtongkong ${ }^{1,2}$ and Edward L. Webb ${ }^{1,3}$
}

\begin{abstract}
In Thailand, mangrove forests are claimed for state management, although it is widely recognized that coastal communities access and manage those forests. Skepticism persists within Thai government circles about whether coastal villages can sustainably manage and protect mangroves. This research presents evidence of successful mangrove conservation and management by two coastal villages in Trang province, southern Thailand. Using interdisciplinary methods including interviews, discussions, quantitative forest surveys, and institutional analysis, we describe the history of how these two communities gained rights to manage the mangrove forests, and the subsequent positive biological outcomes associated with their management. Local villages have crafted and maintained well-defined governance management institutions over the forest, and as a result, stand structure was superior in community-managed mangrove forests than in the open-access state forest. We argue that the basis for the communities' success in managing these forests was that the resource was necessary to local livelihoods and was becoming scarce; the communities enjoyed autonomous decision making and had a high degree of social capital; the forest and user groups were well defined and monitored; effective leadership was present in the villages to apply sanctions and resolve conflicts; and there was substantial assistance from an external non-governmental organization, which served as a bridge between the villages and the government. For conservation, simply knowing whether communities can conserve mangroves is not sufficient. We must know why the communities are or are not successful. Conservation research must, therefore, consider not only the biological outcomes of community management, but the underlying reasons for those outcomes. This paper can serve as a guideline for future studies on the community-mangrove interface.
\end{abstract}

Key Words: biodiversity; collective action; ecology; forest management; institutions; management; sustainability

\section{INTRODUCTION}

The environmental importance of mangroves has been widely demonstrated (e.g., Othman 1994, Nagelkerken et al. 2000, Kathiresan and Rajendran 2005), as has their direct and indirect contributions to the livelihoods of millions of coastal inhabitants (Sathirathai and Barbier 2001, Soontornwong 2006). Unfortunately, however, mangroves are seriously threatened ecosystems (Valiela et al. 2001), with threats coming from coastal development, conversion to aquaculture, overharvesting of trees, pollution, and global climate change (Adeel and Pomeroy 2002, Alongi 2002). Southeast Asia is considered to be a center of mangrove diversity (Tomlinson 1986); therefore, conservation of Southeast Asian mangroves is a high priority. There is an urgent need to find conservation strategies that lead to successful biological outcomes, while accounting for the needs of rural coastal inhabitants who depend on the resource.

There is extensive documentation that in many upland systems of South and Southeast Asia, local forest protection and management has led to an improvement of forest conditions (e.g., Agrawal and Ostrom 2001, Gautam et al. 2002, Kabir and Webb 2006). This has led to a shift in policies and action toward decentralization and local management (Webb 2008). In contrast, surprisingly little is known about the impacts of community management on coastal mangrove forests, with the exception of the Philippines, where communitybased coastal management projects have existed for

\footnotetext{
${ }^{1}$ Asian Institute of Technology, ${ }^{2}$ Rajamangala University of Technology Srivijaya, ${ }^{3}$ Department of Biological Sciences, National University of Singapore
} 
more than 20 years (Pomeroy and Carlos 1997, Alcala 1998, Katon et al. 2000, Walters 2000, 2003). Indeed, it has been recognized for some time that community-based coastal management shows promise, but its integration into national management systems would require significant effort on the part of governments to reorient legal and policy instruments to include local communities (Pomeroy 1995).

In Thailand, mangrove forests are claimed and managed by the state (Aksornkoae 2004). The central government centralized and monopolized the control and management of natural resources together with the process of territorialization (Ganjanapan 2003, Webb 2008). Subsequently, mangroves were put under strict control by the state agencies, and settlement or forest utilization by local people in mangrove conservation zones is prohibited (Aksornkoae 2004). Early assessments of coastal management policy for Thailand failed to recognize the potential of communities in the process (Tabucanon 1991). State mangrove forest management can occur without the participation of local people, which not surprisingly has declined since the government claimed control and management of natural resources (Ganjanapan 2003). Past failings of state management are reflected in the decline in mangrove area from 372 448 ha in 1960 to between 167500 and 244000 ha in the late 1990s (Wilkie and Fortuna 2003).

In southern Thailand, degradation of mangroves has prompted many communities to initiate local organization and collective action for mangrove conservation (Rittibhonbhun et al. 1993), and coastal communities are interested in gaining rights to mangroves under a community forestry umbrella (Sathirathai 1997). However, skepticism persistsparticularly within Thai government circles - about the capacity of local people to sustainably manage and protect mangrove forests. Research on the effects of different management models on mangrove ecosystems will inform the current debate, but to date no research has assessed the effectiveness local community management of mangroves in Thailand.

How can community management of mangroves be assessed for conservation outcomes? Quantitative surveys can report biological outcomes, but when the resource is managed by local communities, social data are also needed, to explore the contextual factors associated with those outcomes. For mangroves, this has yet to be accomplished, although in upland forested systems interdisciplinary studies are becoming more common (Kijtewachakul et al. 2004, Gautam and Shivakoti 2005).

Here we present a case study of four mangrove forests under two management systems: state management and community management. We used a combination of methods to evaluate the relative conservation outcomes of state and community management on the mangrove forests of Trang Province, southern Thailand. This paper presents not only an evaluation of these two management systems in Thailand, but also serves as an example of how interdisciplinary research can be performed in coastal systems of the tropics.

State forest refers to mangrove forests owned and managed by the state, where communities have limited or no rights to access, withdraw, or manage resources. Community forest management refers to a system where a locally derived formal governance structure has been developed to manage, protect, and use the forest resources. The objective of the study was to compare the conditions of the mangrove ecosystem under community and state management. We report that, in our study area, local communities have been effective stewards of mangrove forests. The findings of this research will be useful for developing mangrove management using community-based approaches.

\section{METHODS}

\section{Research Site}

Trang province is located in southern Thailand between $7^{\circ} 15^{\prime}-7^{\circ} 45^{\prime} \mathrm{N}$ and $99^{\circ} 15^{\prime}-99^{\circ} 45^{\prime} \mathrm{E}$ on the coast of Andaman Sea (Fig. 1). The climate is tropical seasonal monsoon, with a rainy period from June to November and an annual rainfall of 1830 $1861 \mathrm{~mm}$. The annual mean temperature of the study site is $27.5^{\circ} \mathrm{C}-27.6^{\circ} \mathrm{C}$. Local tides have a semidiurnal regime with maximum amplitudes of $2.9 \mathrm{~m}$.

Mangrove forest covers ca. $4918 \mathrm{~km}^{2}$ in Trang, in the districts of Sikao, Kantang, Yan Takao, and Palian. The dominant genera of these coastal mangroves are Rhizophora, Ceriops, and Bruguiera (Aksornkoae 1993). According to categories described by Duke et al. (1998), Trang mangrove forests can be categorized as downstream or upstream estuarine, which we refer to in this paper 
Fig. 1. Map of the studied mangrove community forests (CF) and state forests (SF) in seaward and landward sites in Trang, southern Thailand.

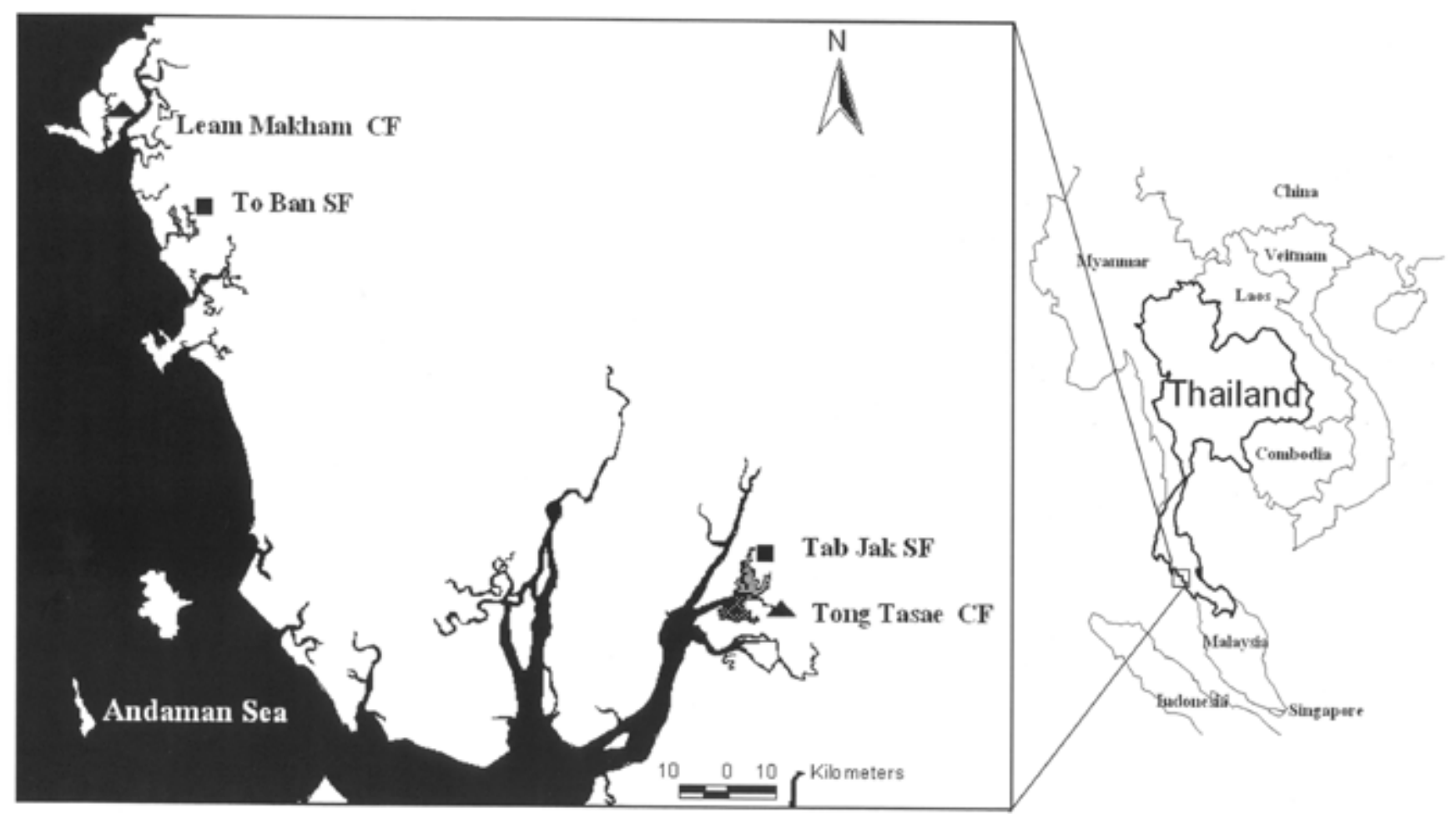

as seaward or landward, respectively. Seaward mangrove locations are mainly distributed along the Andaman coastline, particularly in Sikao and Kantang districts, whereas landward mangrove forests are found in Yan Takao and Palian districts. Locational differences are expected to influence the dominant species and composition of the forests (Duke et al. 1998).

This research focused on the management and conservation of four mangrove forests in a paired design at one seaward and one landward site (Fig. 1). Each site had one forest that was under state management, and another forest that was under community management. The landward forests were accessed and used by Tab Jak (state forest, SF) and Tong Tasae villages (community forest, CF), and the seaward forests were accessed and used by To Ban (SF) and Laem Makham villages (CF). Village descriptions and histories are given in the Results section.

\section{Survey Design}

To gather information on community forest establishment and local management practices at each site, key informant interviews and informal group discussions were conducted at each village. Seven to eight key informants were deliberately selected from among elderly villagers, leaders, and members of the community forest committee. At least five informal group meetings were conducted at each village. Moreover, knowledgeable and experienced villagers (especially village leaders and elders) were interviewed to gather information on state management practices. The interviews and discussions focused on numerous aspects of the villages' relationships with the mangroves, particularly the history of villages, traditional uses of the mangroves, conflicts with outside interests, history and mechanism of community forest user group (CFUG) formation, mangrove management and protection practices, and rules governing those practices (i.e., institutions sensu Ostrom 1990). 
To compare the forest condition of community- and state-managed mangrove forests, vegetation surveys were conducted between 2004 and 2006 using methods adopted from English et al. (1994). Twenty-two $10 \mathrm{~m} \times 10 \mathrm{~m}$ vegetation plots were established at random locations in each forest. In each plot, the girth at breast height $(\mathrm{GBH}$ at $1.3 \mathrm{~m}$ height) of each stem with a GBH $\geq 4 \mathrm{~cm}(1.27 \mathrm{~cm}$ diameter at breast height (dbh)) was measured, and height was calculated using a Sunnto ${ }^{\circledR}$ clinometer. The GBH was converted into dbh and basal area (BA). Species identification was done with assistance from the reference materials of Tomlinson (1986) and Aksornkoae et al. (1992).

\section{Data Analysis}

Abundance, basal area, frequency, and importance value for each species were computed following the procedure of English et al. (1994). The computer program PRIMER 5.0 (Clark and Warwick 1994) was used to compute diversity and similarity indices of each forest. Diversity indices included richness, Margalef's index (Margalef 1958), the Shannon index $\left(\mathrm{H}^{\prime}\right)$ (Shannon and Weaver 1949), Pielou's evenness ( $\left.\mathrm{J}^{\prime}\right)$ (Pielou 1975), and Hill's index (Hill 1973). The Bray-Curtis Similarity Index (Bray and Curtis 1957) was calculated to determine the similarity of tree species composition across forests.

\section{RESULTS}

In order to get a clear understanding of the villagelevel dynamics and relationship with the mangroves, especially the influence of communitybased management, detailed accounts of the site histories and management practices at each site are given below. These accounts were consolidated from interviews and discussion group data. Following the contextual descriptions, we present the biological outcomes of state and community forest management regimes.

\section{Site Histories, Management, and Development of Community Mangrove Forests}

Tab Jak and Tong Tasae are inland villages that have similar physical features and community characteristics. Both of the villages are small, rural Muslim communities. Most villagers earn their primary incomes from rubber tapping in private plantations. In addition, villagers collect mangrove products (fish, crabs, mollusks, honey, and Nypa leaves) for local consumption and sale in the local market. Mangrove trees are traditionally used for housing materials and to make fishing equipment. Thus, local village life depends substantially on the nearby mangrove forest.

Leam Makham and To Ban are seaward coastal villages, and the inhabitants are primarily Muslim. Nearshore fishing of fish, squid, and crab is the primary source of income. In addition, fishers collect fish and crabs in the local mangrove forest. Mangrove forest also provides materials for house and fish cage construction.

In Thailand, the Royal Forest Department (RFD) claimed legal rights over mangroves through the 1941 revision of the 1913 Forest Protection Act (Webb 2008). In the study area, the RFD began approving mangrove harvesting concessions that same year, allowing commercial interests to extract mangroves - principally Rhizophora apiculata and occasionally $R$. mucronata - for charcoal production. Concessions were renewable 10-year contracts between the business and the RFD. Although the RFD system called for rotational harvesting, in practice this never occurred and harvesting was done simultaneously across an entire concession. The concessionaire would hire both local villagers and outsiders to cut Rhizophora for the kilns, paying by weight harvested. As a result, harvesting targeted large trees first and then focused on smaller sizes as the populations were depleted: down to $5-\mathrm{cm}$ diameter and even including root material.

Concessions ran continuously in To Ban, and near Laem Makham and Tong Tasae from the early 1940s. Concessions also ran in Tab Jak from the same time, but because the forest was not dominated by $R$. apiculata, only part of the study site was in charcoal concession. Concessions stopped in Tab Jak in 1999, and To Ban in 2002.

In addition to concessions, illegal timber harvesting was common in state forests. Timber harvesting targeted Xylocarpus moluccensis and X. granatum. In general, harvesting was done to meet timber demands outside the village, and was done by a few people inside and outside the local villages.

The historical trends and events leading to the establishment of mangrove community forests in Tong Tasae and Laem Makham village had many 
parallel features (Table 1). Before the 1940s at both sites, each village had traditional use and management rights over a section of mangrove forest that was recognized by other villages. These "village mangrove forests" were governed by informal structures and rules that were understood within and across villages. The objective of a village forest was for harvest by villagers for their own benefit, with a set of informal but widely recognized rules governing withdrawal and management.

At Tong Tasae and Laem Makham, the village mangrove forest was not included in the original concession agreement between the RFD and the concessionaires. However, at both sites, respondents acknowledged that illegal mangrove cutting by the concessionaires within their village forests led to ecosystem degradation, which reduced the availability of important fisheries products. This served as a principle motivating force for a group of five to six people within each village to form a "conservation group" and initiate conservation action. The conservation groups attempted to hold dialogues with concessionaire workers to prevent cutting in their forests, along with marking the boundaries of the village forests. In addition, the conservation group members disseminated their message by opportunistically discussing the problems and possible solutions with other village members. Dialogues with the concessionaire workers were ineffective at both villages, and illegal cutting within the forests by the concessionaires continued.

When Laem Makham village reported illegal concessionaire cutting to the district RFD office, the district governor warned the concessionaire, causing further conflict between the village and the concessionaire, leading to the assassination of one of the group members in 1988. The assassination in Laem Makham produced an atmosphere of fear in the village toward the concessionaire, which reduced mangrove conservation activities by the community. At the same time, a local nongovernmental organization (NGO), the Yadfon Association (YFA), with international donor support, initiated capacity-building activities for coastal resource management in Laem Makham. The YFA offered conservation group members training, field visits, and discussions with academics. After the assassination, YFA staff also partnered with conservation group members to improve mangrove conservation strategies.
Laem Makham conservation group members and the YFA concluded that establishing a mangrove conservation network would be a critical step in the long-term strategy for mangrove protection. In 1989, Laem Makham village invited the provincial governor, district officers, foresters, and neighboring villagers to participate in a mangrove replanting project in a small section of the village mangrove forest. The participation of the governor and concerned officials signaled recognition of the conservation group by the governor, which reduced conflict between the concessionaire and villagers. The conservation group then notified all villagers in Laem Makham and in neighboring villages that the section of forest that had been replanted was now protected by new rules crafted by the conservation group, i.e., it was a CF. Approximately 6 months later, the district forest office sent its staff to delineate the entire Laem Makham village mangrove forest with boundary signs encircling ca. 80 ha of forest. In 1994, a formal mangrove community forest committee (MCFC) was established in Laem Makham, (initially consisting of eight to nine members of the growing conservation group) to govern the entire 80 ha. Subsequently, a meeting was held among villagers, neighboring villages, the RFD, and NGOs to declare the 80 ha as the Laem Makham Community Forest. The forest was divided into three management zones: conservation (ca. 16 ha), utilization (ca. 64 ha), and medical (ca. 0.3 ha).

Rules prohibited mangrove cutting within the conservation zone, but timber and forest products could be harvested within the utilization zone with the permission of the MCFC. Since 1994, Laem Makham conservation group members have expanded their mangrove conservation campaign to neighboring villages and neighboring districts to seek wider support and to strengthen the mangrove conservation network. This has resulted in the formation of $\mathrm{CFs}$ in nearby villages.

Events leading to the formation of Tong Tasae CF occurred more recently than in Laem Makham. In 1991, evidence of mangrove degradation from illegal cutting by the concessionaire and local people became evident. When Tong Tasae village reported illegal concessionaire cutting to the district RFD office, the authorities largely ignored them. The local government provided neither support for conservation activities nor acknowledgment of village rights to protect and manage the forest. Nevertheless, lack of local forester attention did not 
Table 1. Important historical events related to mangrove community forest establishment at two sites in Trang, southern Thailand.

\begin{tabular}{l}
\hline \hline Year Tong Tasae \\
\hline 1941 \\
$1943 \begin{array}{l}\text { Outside businessmen started mangrove concessions for } \\
\text { charcoal production. }\end{array}$
\end{tabular}

1982

1984

\author{
Laem Makham
}

Outside businessmen started mangrove concessions for charcoal production.

The degradation of mangrove was apparent in the village. Informal discussions between the leader and active villagers often included issues related to mangrove degradation caused by illegal cutting.

Informal committee was established. They initiated monitoring of illegal practices by charcoal concessionaires and reported the situation to foresters.

A local NGO, the Yadfon Association (YFA), started working in the community. The YFA supported leaders and active group members by facilitating training, field visits, and dialogue with academics. The aim of these activities was to empower local people to develop community-based mangrove management in their community.

Conflict increased between community members and charcoal concessionaires because of illegal practices in the village forest. The informal conservation group made futile attempts to negotiate with the charcoal plant, and reported the occurrence to government agencies. An active leader was assassinated for informing officials of illegal mangrove cutting.

The village leaders, group members, and the YFA begin to develop a network of conservation groups in this region and encouraged concerned officials to work together with local people.

With the assistance of the YFA, the governor, foresters, and neighboring villagers, local villagers established a community forest to conserve mangrove forest with a limited level of use.

1991 Mangrove degradation became evident, leading to informal discussions among members of the community. It was concluded that illegal mangrove cutting was the most important cause of the degradation.

1992 Leaders and active community members started campaigning to protect the mangrove forest.

The community marked the village mangrove forest with boundary signs.

The aim of the activities was to protect the forest from illegal cutting caused by charcoal concessionaires. However, villagers did not receive any support from local foresters, who believed that the mangroves should be centrally managed by the state. 
1993 The leader and active community members persuaded community members to join in a mangrove plantation project surrounding village.

1994

1995 A local NGO, the Yadfon Association (YFA), started working in the village. The YFA supported leaders and their staff by facilitating training, field visits, and dialogue with concerned government agencies.

1997 The leader proposed a community forest project to the regional forestry office. Meetings among villagers, foresters, academics, and NGOs resulted in the establishment of a 320-ha mangrove community forest. Tong Tasae Community forest has been maintained without legally enshrined rights
The mangrove community forest was enlarged to 80 ha and divided into three parts: a conservation zone, a utilization zone, and a medical zone. The village has been maintaining the mangrove community forest through to the present day. diminish their attempts to conserve the forest. Information campaigns were continually conducted by the leader to improve awareness and seek wider support from villagers. In 1992, the community marked the boundary of a 320-ha village mangrove forest with signs, but was cautioned by the RFD that any extraction or "detrimental" management activities would result in arrest. In 1993, the conservation group invited community members to join in a mangrove plantation project in the village mangrove forest. In 1995, the YFA initiated capacity-building activities in Tong Tasae, encouraging conservation group members to attend training, field visits, and discussions with academics and government officers. The YFA staff also partnered with conservation group members to find better mangrove conservation strategies after they did not get any support from local foresters. Tong Tasae conservation group members and the YFA concluded that they should contact the regional RFD office and explain their activities in protecting the mangrove forest.

In 1997, the conservation group leader sent documents to the regional forestry office to explain their conservation and management activities, and to propose the establishment of a CF. A meeting was held among villagers, the RFD, academics, and NGOs that resulted in the designation of the village mangrove forest as a $\mathrm{CF}$. The conservation zone covered ca. $40 \%$ of the total community forest area, i.e., 128 ha, with the remainder (ca. 192 ha) in the utilization zone.

A formal MCFC was established in the village, initially consisting of nine to ten conservation group members. The MCFC produced governance documents describing the structure of the committee and duties of each member. This document was displayed in the CF center, a small building for use by CFUG members.

It is important to note that both the Laem Makham and Tong Tasae CFs were established and operated without legal rights from the RFD over mangrove forest management, even though they were informally recognized by the RFD, the local government (in the case of Laem Makham), and other villages as CFs. All activities by the villagers before 1997 occurred with no legal rights under Thai law. Although the Thai Constitution of 1997 provided general rights to local people to engage in resource conservation, no laws specifically designated community rights over mangroves. 


\section{Community Forest Governance and Management}

The institutional arrangements for $\mathrm{CF}$ and SFs at the two sites are given in Table 2. At both sites, membership in the CFUG is open to anyone in the village who verbally expresses an interest in membership during a CFUG meeting. Membership in the CFUG provides more harvesting rights to the member (see below), but requires participation in rehabilitation (mangrove replanting projects) and monitoring. The MCFC consists of CFUG members who are selected for leadership by the group. Membership in the MCFC has no term limit, but members can be replaced when they move out of the village or do not fulfill their duties. A former headman in Tong Tasae and a former religious leader/headman in Laem Makham were chosen as the chairmen of their respective MCFCs.

In the conservation zones at both sites, anyone (including non-village and non-CFUG members) can access the forest and harvest honey and fisheries products (fish, crabs, mollusks, shrimp) using legal methods only. In Tong Tasae, a minimum harvestable size for crabs was agreed upon by all villagers accessing that $\mathrm{CF}$. In addition, in 2005 , Tong Tasae changed mud crab harvesting rules to allow harvesting only during the full moon day and night each month. Harvesting of medicinal plants was allowed for CFUG and non-CFUG members of each village, but not outsiders.

Rules governing use, management, protection, and sanctions were created by the MCFC. Proposed rules are voted on by CFUG members, and a rule is only passed if $80 \%$ are in favor. For the utilization zones, rules were consistent across the two sites. Access rights were granted to anyone from any village, and those persons could withdraw honey and fisheries products at any time. Village members could harvest medicinal plants and trees of Rhizophora for household use of charcoal and fuelwood. Around the year 2000, households began converting to liquefied petroleum gas (LPG) and electricity as fuel sources, so harvesting for charcoal and fuelwood declined. Members of the CFUG could seek approval to cut timber for house construction, but would have to replant five mangrove seedlings for each tree harvested. Timber harvesting by CFUG members was rarely done. In Tong Tasae, only two households ever exercised their rights to harvest timber, to rebuild houses that had burned down. In Laem Makham, timber was harvested once to build a small open-air meeting room (sala in Thai).

Forest monitoring in Laem Makham has been done by the CFUG since the establishment of the CF. The CF is located next to a well-traveled canal, so CFUG members pass the CF on a daily basis on the way to fishing activities in the open ocean. The Tong Tasae $\mathrm{CF}$ was not visited on a daily basis by CFUG members and, therefore, required intensive patrolling by the MCFC during the initial stages of CF establishment (3-4 years). Thereafter, monitoring became less frequent, occurring only when CFUG members accessed the forest to harvest products.

To prevent inappropriate harvesting, both Tong Tasae and Laem Makham erected signboards displaying the basic rules and sanctioning system of the CFUG. When illegal activities were observed, the CFUG member would report to the MCFC, who would send two or three MCFC members to open a dialogue with the violators and the headman of the other village (if the violator lived outside the village) to explain the rules of the $\mathrm{CF}$. According to the interviews, in all cases, this prevented further encroachments into the $\mathrm{CF}$ by non-village members. However, the CFUGs retained the right to increase sanctions for multiple offenders, such as a monetary fine from 1000 to 10000 Thai Baht (ca. U.S.\$37$\$ 373$, based on the conversion rate in effect 11 August 2007) for second-time violators, and legal action with the cooperation of patrol police for thirdtime offenders.

At both Laem Makham and Tong Tasae, the MCFCs set up rehabilitation activities to improve mangrove forest condition. Rehabilitation activities included replanting Rhizophora, Avicennia, and Bruguiera seedlings collected from the forest, and weeding of climbers and unwanted shrubs. In Tong Tasae, these activities occurred almost monthly; in Laem Makham, activities were not regularly planned. Over the 30 months of this research, Laem Makham conducted replanting and weeding activities three times.

\section{Forest Composition and Diversity}

In Tong Tasae, all 22 vegetation survey plots fell within the utilization zone. In Laem Makham, 19 of 22 plots fell within the utilization zone. Thus, the results presented here for the CFs reflect the 
Table 2. Institutional arrangements over community and state forests at two sites in Trang, southern Thailand.

\begin{tabular}{lll}
\hline \hline Rule (Institution) & Tong Tasae CF & Tab Jak SF \\
\hline $\begin{array}{l}\text { Exclusion of outsiders by } \\
\text { village }\end{array}$ & $\begin{array}{l}\text { No restrictions on } \\
\text { entering the forest }\end{array}$ & $\begin{array}{l}\text { No restrictions on } \\
\text { entering the forest }\end{array}$ \\
$\begin{array}{l}\text { Clearly defined } \\
\text { boundary }\end{array}$ & $\begin{array}{l}\text { CF boundary is clearly } \\
\text { marked with signs }\end{array}$ & No boundary signs \\
&
\end{tabular}

Management group

Appropriation

Monitoring or patrolling

Ability to detain illegal harvesters

Graduated sanctions

Link with government authority forest committee group (MCFC)

Wood cutting allowed Wood cutting is only for CFUG members with permission from MCFC

Began as scheduled patrols by MCFC. At present, occurs informally on an almost daily basis during other management and harvesting activities (e.g., fishing, honey collection, crab collection)

The MCFC has full power to arrest rule breakers because some MCFC members are "patrol police" officers (combined military and domestic) who work in the village

Yes: sanction depends on the frequency of violation

The RFD and local police have the authority to arrest

Very infrequently by state officers
Mangrove community No local management prohibited by state law violators of state law

Mangrove community forest committee (MCFC)

Laem Makham CF To Ban SF

No restrictions on

entering the forest

No restrictions on

CF boundary is clearly Only one sign in marked with signs

Wood cutting allowed only for CFUG members with permission from MCFC

By four to five $\mathrm{CF}$ user-group member households, occurs almost daily (during good weather) when passing by the forest on the way to the open ocean for fishing

The MCFC cannot arrest rule breakers; the RFD and local police have the authority to arrest violators of state law
Villagers managed their mangrove forest with close collaboration of patrol responsibility police who work at the local people primary school
None: the punishment is applied according to state law

The RDF manage the mangrove forest without sharing local people
Yes: sanction depends on the frequency of violation

Villagers managed their mangrove forest with the cooperation of the government authority
Very infrequently by state officers
The RFD and local police have the authority to arrest violators of state law village declaring that forest belongs to state, but no boundary markers

No local management group

Wood cutting is prohibited by state law

None: the punishment is applied according to state law

The RDF manage the mangrove forest without sharing responsibility with local people 
condition of the utilization zone and should be considered a conservative estimate of the (positive) impact of community management on forest structure and diversity.

A total of 21 tree species in 3298 stems were recorded in the four forests, 12 species in Tong Tasae CF, 11 in Tab Jak SF, 9 in Laem Makham $\mathrm{CF}$, and 14 in To Ban SF (Table 3). Tong Tasae (inland) was dominated by Xylocarpus moluccensis, with Heritiera littoralis, Xylocarpus granatum, Ceriops decandra, and Excoecaria agallocha far less important (Table 4). In Tab Jak (inland), the most important species were Rhizophora apiculata, $X$. moluccensis, and X. granatum (Table 4). Laem Makham (seaward) was dominated by $R$. apiculata with $C$. decandra and Bruguiera parviflora a distant second and third in importance, respectively (Table 4). In To Ban (seaward), R. apiculata was the most important species, followed by $C$. decandra (Table 4). The high importance of Xylocarpus spp. mixed with $R$. apiculata in the inland sites, and the heavy dominance of $R$. apiculata in the coastal sites agrees with mangrove inventories in Thailand and the Indo-Pacific regions (Smith 1992, Aksornkoae 1993, Ashton and Macintosh 2002, Macintosh et al. 2002).

The Bray-Curtis Similarity Index between the CF and SF within a site was 72.5 (landward) and 74.1 (seaward), indicating high species overlap (Table 5). Similarity across forests was lower, ranging from 39.3 to 53.9. Tong Tasae, being dominated by $X$. moluccensis, had the least similarity with any other site.

Landward sites were generally more diverse, and with species more evenly distributed, than the seaward sites (Table 6). Diversity indices revealed that the CF and SF in the landward site were similar in species diversity and evenness. At the seaward site, species diversity at the SF was higher than at the $\mathrm{CF}$, whereas evenness indices of tree species were not different. Hill's index was lowest in Laem Makham because of the very heavy dominance of Rhizophora apiculata in that forest (Table 6).

\section{Forest Structure}

Forest structural parameters varied across the four mangrove forests. Mean plot stem density was 1373 $\mathrm{ha}^{-1}$ in Tong Tasae CF vs. $3096 \mathrm{ha}^{-1}$ in Tab Jak SF (independent sample $t$-test with equal variances, $d f$ $=42, \mathrm{t}=-4.45, p<0.0001)$, and $4868 \mathrm{ha}^{-1}$ in Laem Makham CF vs. $5655 \mathrm{ha}^{-1}$ in To Ban SF (independent sample $t$-test with unequal variances $n=44, d f=35, t=-1.236, p>0.05)$. Basal areas in the CFs were significantly greater than in the SFs: $78.3 \mathrm{~m}^{2} \mathrm{ha}^{-1}$ in Tong Tasae vs. $15.4 \mathrm{~m}^{2} \mathrm{ha}^{-1}$ in Tab Jak (independent sample $t$-test with unequal variances, $d f=23, t=5.592, p<0.0001)$ and 22.1 $\mathrm{m}^{2} \mathrm{ha}^{-1}$ in Laem Makham vs. $9.8 \mathrm{~m}^{2} \mathrm{ha}^{-1}$ in To Ban (independent sample $t$-test with equal variances, $d f$ $=42, t=6.599, p<0.0001)$ (Table 7).

There were differences in the tree size-class distributions between SFs and CFs (Fig. 2). In Tong Tasae CF, maximum tree diameter was $124.7 \mathrm{~cm}$ (X. moluccensis), $36.1 \%$ of the trees had diameters $>10 \mathrm{~cm}$, and $18 \%$ of the trees were $>30 \mathrm{~cm} \mathrm{dbh}$. In contrast, in Tab Jak SF, maximum tree diameter was $59.8 \mathrm{~cm}(X$. granatum $), 8.8 \%$ of trees were $>10 \mathrm{~cm}$ $\mathrm{dbh}$, and $1.2 \%$ of trees were $>30 \mathrm{~cm} \mathrm{dbh}$. The sizeclass distributions were statistically different $(n=$ 983, Mann-Whitney U test, $\mathrm{z}=-7.425, p<0.0001$ ). A similar trend of larger trees in CFs was evident at the seaward sites, although overall tree size was much smaller than at the inland sites because the sites were dominated by $R$. apiculata rather than $X$. moluccensis. In Laem Makham $\mathrm{CF}$, maximum tree size was $31.3 \mathrm{~cm}(A$. alba) and $33.5 \%$ of the trees were $>8 \mathrm{~cm}$ dbh. In To Ban SF, maximum tree $\mathrm{dbh}$ was $31.8 \mathrm{~cm}$ (A. marina) and $5.3 \%$ of the trees were $>8 \mathrm{~cm}$ dbh. Size-class distributions were statistically different $(n=2315$, Mann-Whitney U test, $\mathrm{z}=-16.37, p<0.0001)$.

Comparing size-class distributions of the most dominant species at each site revealed significant differences between CFs and SFs (Fig. 3). In the landward sites, the population of $X$. moluccensis in Tong Tasae CF contained larger individuals than in Tab Jak SF $(n=171$, Mann-Whitney U test, $\mathrm{z}$ $=-5.677, p<0.0001)$. Similarly, the trees in the $R$. apiculata populations in Laem Makham CF were larger than in To Ban SF $(n=1324$, Mann-Whitney $\mathrm{U}$ test, $\mathrm{z}=-15.731, p<0.0001)$.

The height-class distribution of trees showed that at both landward and coastal sites, CFs had taller trees than SFs (Fig. 4). For example, $21.5 \%$ of the trees in Tong Tasae CF were taller than $15 \mathrm{~m}$, compared with $3.1 \%$ of the trees in Tab Jak SF $(n=983$, Mann Whitney U test, $\mathrm{z}=-4.902, p<0.0001)$. Similarly, $10.8 \%$ of the trees in Laem Makham CF were taller than $15 \mathrm{~m}$, whereas no trees of this height class were 
Table 3. Species composition and structural features of all stems $\geq 1.27 \mathrm{~cm} \mathrm{dbh}$ in four mangrove forests in Trang, southern Thailand. CF: community forest, SF: state forest. \#/ha: number of trees per hectare, RA: relative abundance, BA/ha: basal area per hectare $\left(\mathrm{m}^{2}\right), \mathrm{RBA}$ : relative basal area. Species that were present but with a BA or RBA of less than 0.01 are listed as 0.00 .

\begin{tabular}{|c|c|c|c|c|c|c|c|c|c|c|c|c|c|c|c|c|}
\hline \multirow[b]{3}{*}{ Species } & \multicolumn{8}{|c|}{ Landward mangrove } & \multicolumn{8}{|c|}{ Seaward mangrove } \\
\hline & \multicolumn{4}{|c|}{ Tong Tasae (CF) } & \multicolumn{4}{|c|}{ Tab Jak (SF) } & \multicolumn{4}{|c|}{ Laem Makham (CF) } & \multicolumn{4}{|c|}{ To Ban (SF) } \\
\hline & \#/ha & RA & $\begin{array}{l}\mathrm{BA} / \\
\mathrm{ha}\end{array}$ & $\mathrm{RBA}$ & \#/ha & RA & $\begin{array}{l}\mathrm{BA} / \\
\text { ha }\end{array}$ & RBA & \#/ha & RA & $\begin{array}{l}\mathrm{BA} / \\
\mathrm{ha}\end{array}$ & $\mathrm{RBA}$ & \#/ha & RA & $\begin{array}{l}\mathrm{BA} / \\
\mathrm{ha}\end{array}$ & RBA \\
\hline Amoora cucullata & & & & & & & & & & & & & 5 & 0.08 & 0.00 & 0.03 \\
\hline Avicennia alba & 23 & 1.66 & 0.75 & 0.96 & 127 & 4.11 & 1.81 & $\begin{array}{c}11 .- \\
73\end{array}$ & 41 & 0.84 & 1.15 & 5.21 & & & & \\
\hline Avicennia marina & & & & & 32 & 1.03 & 1.21 & 7.88 & & & & & 5 & 0.08 & 0.36 & 3.69 \\
\hline Avicennia officinalis & & & & & & & & & 136 & 2.8 & 0.11 & 0.5 & 9 & 0.16 & 0.27 & 2.75 \\
\hline Bruguiera cylindrica & & & & & & & & & & & & & 68 & 1.21 & 0.16 & 1.67 \\
\hline Bruguiera gymnorrhiza & & & & & 9 & 0.29 & 0.07 & 0.48 & & & & & & & & \\
\hline Bruguiera parviflora & & & & & 18 & 0.59 & 0.07 & 0.46 & 259 & 5.32 & 0.44 & 2 & 73 & 1.29 & 0.13 & 1.29 \\
\hline Bruguiera sexangula & 50 & 3.64 & 0.17 & 0.22 & 386 & $\begin{array}{r}12 .- \\
48\end{array}$ & 0.63 & 4.06 & & & & & & & & \\
\hline Caesalpinia bonduc & 9 & 0.66 & 0.00 & 0.00 & & & & & & & & & & & & \\
\hline Ceriops decandra & 305 & $\begin{array}{r}22 .- \\
19\end{array}$ & 0.23 & 0.29 & 632 & $\begin{array}{r}20 .- \\
41\end{array}$ & 0.56 & 3.61 & 927 & $\begin{array}{c}19 .- \\
05\end{array}$ & 1.65 & 7.48 & 1350 & $\begin{array}{c}23 .- \\
87\end{array}$ & 1.47 & 14.95 \\
\hline Ceriops tagal & & & & & & & & & 100 & 2.05 & 0.25 & 1.12 & 864 & $\begin{array}{c}15 .- \\
27\end{array}$ & 1.16 & 11.88 \\
\hline Cynometra iripa & 5 & 0.33 & 0.01 & 0.01 & & & & & & & & & & & & \\
\hline Excoecaria agallocha & 123 & 8.94 & 3.74 & 4.78 & 45 & 1.47 & 0.65 & 4.18 & & & & & 9 & 0.16 & 0.09 & 0.95 \\
\hline Heritiera littoralis & 186 & $\begin{array}{c}13 .- \\
58\end{array}$ & 3.48 & 4.44 & 150 & 4.85 & 0.71 & 4.61 & & & & & 5 & 0.08 & 0.00 & 0.01 \\
\hline Rhizophora apiculata & 173 & $\begin{array}{r}12 .- \\
58\end{array}$ & 1.16 & 1.49 & 923 & $\begin{array}{r}29 .- \\
81\end{array}$ & 2.08 & $\begin{array}{r}13 .- \\
47\end{array}$ & 3223 & 66.2 & 17.8 & $\begin{array}{r}80 .- \\
66\end{array}$ & 2795 & $\begin{array}{r}49 .- \\
44\end{array}$ & 5.51 & 56.24 \\
\hline Rhizophora mucronata & & & & & & & & & 141 & 2.89 & 0.48 & 2.16 & 223 & 3.94 & 0.15 & 1.49 \\
\hline Scolopia macrophylla & 5 & 0.33 & 0.00 & 0.00 & & & & & & & & & & & & \\
\hline $\begin{array}{l}\text { Scyphiphora hydro- } \\
\text { phyllacea }\end{array}$ & & & & & & & & & & & & & 5 & 0.08 & 0.03 & 0.32 \\
\hline Sonneratia griffithii & 45 & 3.31 & 6.34 & 8.1 & & & & & & & & & & & & \\
\hline
\end{tabular}




\begin{tabular}{|c|c|c|c|c|c|c|c|c|c|c|c|c|c|c|c|}
\hline Xylocarpus granatum & 95 & 6.95 & 6.39 & 8.16 & 350 & $\begin{array}{c}11 .- \\
31\end{array}$ & $\begin{array}{r}21 .- \\
93\end{array}$ & 23 & 0.47 & 0.14 & 0.64 & 14 & 0.24 & 0.00 & 0.04 \\
\hline Xylocarpus moluccensis & 355 & $\begin{array}{r}25 .- \\
83\end{array}$ & $\begin{array}{r}56 .- \\
05\end{array}$ & $\begin{array}{r}71 .- \\
55\end{array}$ & 423 & $\begin{array}{c}13 .- \\
66\end{array}$ & $\begin{array}{r}27 .- \\
58\end{array}$ & 18 & 0.37 & 0.05 & 0.22 & 232 & 4.1 & 0.46 & 4.69 \\
\hline Number of Species & 12 & & & & 11 & & & 9 & & & & 14 & & & \\
\hline Sum & 1373 & & 78.3 & & 3095 & 15.4 & & 4868 & & 22.1 & & 5655 & & 9.8 & \\
\hline
\end{tabular}

recorded from To Ban SF $(n=2315$, Mann Whitney $\mathrm{U}$ test, $\mathrm{z}=-22.187, p<0.0001)$.

\section{DISCUSSION}

\section{Biological Outcomes in State and Community Forest}

The pairwise design of this study allowed us to compare the conditions between forests under state and community management in both coastal and inland mangrove communities. Due to the proximity and topographical similarity within each site pair, differences in condition are unlikely to be due to environmental factors; rather the impacts of human activities will result in differences in forest parameters. Differences in human activities are mediated by community institutional settings, i.e., rules and management regimes.

Community forests were in a significantly better condition than state forests when considering forest height and basal area. The high rate of harvesting of $R$. apiculata stems-as small as $5 \mathrm{~cm} \mathrm{dbh-for}$ charcoal production in the coastal SF (Aksornkoae 1993), and Xylocarpus spp. stems for timber at the inland SF (Plathong and Sitthirach 1997), reduced the basal area and height of the forest considerably. Indeed, the population size-class distributions of those extracted species clearly indicated that harvesting had significant impacts on the populations. This result is similar to that found in other mangrove forests, where larger and taller trees are found in greater abundance in protected forests than in cut forests (e.g., Kairo et al. 2002), and where the basal area of uncut forests is substantially greater than in harvested forests (e.g., Walters 2005). In fact, the basal area of the Tong Tasae CF was greater than that found in the UNESCO World Heritage Site of Ranong Biosphere Reserve (Macintosh et al.
2002), highlighting the positive influence of local management and protection on mangrove forest structure.

Stem densities in the SFs were generally higher than in the CFs, and this is attributable to high rates of regeneration after disturbance. Mangroves can regenerate prolifically as long as there are sufficient seed trees to contribute propagules (Ashton and Macintosh 2002). For example, Smith and Berkes (1993) reported higher density of small stems in mangrove forest subject to cutting, compared with uncut forest, whereas the density of medium and large trees in managed forests will be much lower than that in uncut forest (e.g., 5\%-30\% of uncut forest, Walters (2004)).

In contrast to the easily observable structural differences, diversity indices were similar across forests. This is because extirpation of species from a site (i.e., reduction in diversity) requires much greater harvesting intensity than that required to change structural features. High regeneration density, combined with the retention of most of the biodiversity, indicates that the SFs could be rehabilitated and could return to their former condition if properly managed and protected.

Our interpretation of these results-particularly structural differences-is that community management was the principle factor in protecting, managing, and conserving the mangrove ecosystem in a manner superior to conventional state management outside of protected areas. This is an important conclusion, because most terrestrial and coastal ecosystems are outside of the protected area system, and strategies for conservation of "unprotected" ecosystems must be developed. Community-based mangrove management and protection, therefore, provides one possible mechanism to achieve the goal of mangrove ecosystem conservation. 
Table 4. The five most important mangrove species, ranked by Important Value Index (IVI) in two community forests (CF) and two state forests (SF) in Trang, southern Thailand.

\begin{tabular}{|c|c|c|c|c|c|c|c|}
\hline \multicolumn{4}{|c|}{ Landward Site } & \multicolumn{4}{|c|}{ Seaward Site } \\
\hline \multicolumn{2}{|l|}{ Tong Tasae (CF) } & \multicolumn{2}{|l|}{ Tab Jak (SF) } & \multicolumn{2}{|l|}{ Laem Makham (CF) } & \multicolumn{2}{|l|}{ To Ban (SF) } \\
\hline Species & IVI & Species & IVI & Species & IVI & Species & IVI \\
\hline Xylocarpus moluccensis & 123.0 & Rhizophora apiculata & 56.9 & Rhizophora apiculata & 178.3 & Rhizophora apiculata & 129.8 \\
\hline Heritiera littoralis & 39.8 & Xylocarpus moluccensis & 55.8 & Ceriops decandra & 52.2 & Ceriops decandra & 56.9 \\
\hline Xylocarpus granatum & 27.9 & Xylocarpus granatum & 49.6 & Bruguiera parviflora & 18.8 & Ceriops tagal & 45.2 \\
\hline Ceriops decandra & 26.3 & Ceriops decandra & 34.0 & Rhizophora mucronata & 15.1 & Xylocarpus moluccensis & 28.1 \\
\hline Excoecaria agallocha & 21.4 & Bruguiera sexangula & 26.5 & Avicennia alba & 8.9 & Avicennia marina & 5.0 \\
\hline
\end{tabular}

\section{Conditions for the Establishment and Long- term Sustainability of Community-based Mangrove Management}

Community-based management is not a panacea for all common-pool resource dilemmas; that is to say, in some cases, community management fails. Promotion of conservation in community-accessed ecosystems requires an understanding of what makes community-based management successful or not. In the case studies of this paper, we have demonstrated that, compared with state management of mangroves, the villages of Laem Makham and Tong Tasae were successful because community management was initiated. Thus, in this section, we apply common-pool resource theory (Agrawal 2003) to our study sites to analyze the reasons for success of the CF sites, and discuss future prospects of long-term sustainable community-based mangrove management in southern Thailand. Specifically, we discuss the following conditions that have been shown to be important for facilitating the emergence and long-term sustainability of collective action over natural resources (Ostrom 1990, Agrawal 2003): necessity and scarcity, local autonomy, social capital, presence of well-defined boundaries, monitoring and sanctions, leadership and conflict resolution, and external support.

\section{Necessity and scarcity}

When local users are dependent on a resource (i.e., the resource is necessary to their livelihoods), the appropriators have an immediate stake in the fate of the resource base. This is an incentive for users to experiment with and craft local management arrangements that supply a flow of the goods while protecting them from overharvesting (Gibson et al. 2000). When a necessary resource becomes or is perceived to become scarce, the incentive for collective action is high, as long as the resource is not degraded beyond the point of feasible improvement (Bardhan 1993, Gibson et al. 2000, Heltberg 2001). In our study sites, users were dependent on mangrove resources for livelihood supplementation, regardless of whether they were rubber tappers or fishers. Threats to the mangroves in the form of illegal logging led to an overwhelming perception that resource scarcity would follow in the absence of some measure of collective action. Thus, the potential (or actual) scarcity of future necessary ecosystem services-particularly the production of fish, shellfish and crabs - was a prime motivating force for the communities to defend their resource. In some parts of Thailand, rural communities are much less dependent on forest resources for their livelihoods than the two villages in this study; in those cases, the level of collective action, and apparent success of community management can be low (Galli 2007).

\section{Local autonomy}

This condition suggests that local resource users have the ability to undertake collective action, and produce rules and regulations over their natural 
Table 5. Similarity of mangrove tree community composition across community-managed (CF) and statemanaged (SF) mangrove forests in Trang, southern Thailand. Similarity was calculated using the BrayCurtis Similarity Index (Bray and Curtis 1957).

\begin{tabular}{lccc}
\hline \hline & Tab Jak (SF) & Laem Makham (CF) & To Ban (SF) \\
\hline Tong Tasae (CF) & 72.5 & 39.3 & 42.3 \\
Tab Jak (SF) & & 51.0 & 53.9 \\
Laem Makham (CF) & & & 74.1 \\
\hline
\end{tabular}

resource base, without challenge from the external authority (i.e., the government). According to the 1997 Thailand Constitution, rights to manage natural resources are provided to local governance systems. Therefore, the CFUG rights to manage CFs are usually not undermined by the external authorities. In southern Thailand, there is a tradition of local organization, and this right is generally recognized by the local authorities. Thus, the CFUGs of Laem Makham CF and Tong Tasae CF enjoyed autonomy to create their own institutions without interference by external government authorities.

Moreover, this autonomy allowed the villages to craft local "collective-choice" arrangements, whereby community members who are affected by the institutions are also participants in the crafting and modifying of those rules. The MCFCs of Tong Tasae and Laem Makham were crucial in making rules governing use, management, and protection of resource, and in the implementation of those rules. As a result, members of the CFUG were more likely to comply with and enforce rules that they themselves participated in making. Hence, autonomy from government interference allowed the local communities to craft locally relevant institutional arrangements over mangrove forests. Such autonomy, as seen through decentralization, is important in allowing local conservation innovation to thrive (Agrawal and Gibson 1999, Webb and Shivakoti 2008).

\section{Presence of well-defined boundaries}

It has been shown in previous research that local cooperation in community management can increase when user groups gain secure rights over the resources and have the authority to exclude outsiders (Ostrom 1990, Hanna and Munasinghe 1995, Johnson 2001, Gibson et al. 2005). This is usually accomplished first by the establishment of clear resource and user group boundaries. Clearly defined resource and user group boundaries can reduce conflict and improve user group compliance with rules (Dietz et al. 2003), reduce uncertainty in resource tenure, and clarify who will pay the cost of collective resource management (Gibson et al. 2005). In Tong Tasae and Laem Makham villages, boundaries were clearly defined through demarcation using signboards, and through face-to-face discussions with external entities infringing on that area. This eventually eliminated the conflict between the CFUG and outside harvesters, and also returned property rights to the CFUG. Restoration of this entitlement supported a CFUG perception that they would receive future benefits for their investments of time, labor, and materials in the $\mathrm{CF}$ management process.

\section{Monitoring and sanctions}

Monitoring is well known to be an important facilitator of long-term sustainable management of resources (Gibson et al. 2005). Monitoring of the two CFs was frequent enough to deter widespread encroachment. By living and working near the mangrove area, local people enjoyed a comparative advantage in monitoring resource use and rule compliance over government agents operating in a SF.

When an encroacher is caught, moreover, graduated sanctions were used to punish offenders. According 
Table 6. Species diversity and evenness of mangrove trees of community-managed (CF) and state-managed (SF) mangrove forests in Trang, southern Thailand.

\begin{tabular}{lcccc}
\hline \hline & \multicolumn{2}{c}{ Landward mangrove } & \multicolumn{2}{c}{ Seaward mangrove } \\
& Tong Tasae $(\mathrm{CF})$ & Tab Jak (SF) & Laem Makham (CF) & To Ban (SF) \\
\hline Absolute richness & 12 & 11 & 9 & 14 \\
Margalef's index & 1.93 & 1.53 & 1.15 & 1.82 \\
Shannon index $\left(\mathrm{H}^{\prime}\right)$ & 1.99 & 1.90 & 1.11 & 1.40 \\
Pielou's index $\left(\mathrm{J}^{\prime}\right)$ & 0.80 & 0.79 & 0.51 & 0.53 \\
Hill's index & 3.87 & 3.35 & 1.51 & 2.02 \\
\hline
\end{tabular}

to Ostrom (1990) graduated sanctions are important because they warn appropriators that any violator will be noticed and punished, and show that those who break the rules repeatedly will meet a heavy penalty. This research found that first-time violators who were warned by the leader and MCFC members never returned to break the rules because they perceived that the cost was higher than the benefit to be received from repeatedly breaking rules. Eventually, rule breaking became an unattractive option for appropriators.

\section{Social capital}

Collective action in Tong Tasae and Laem Makham was supported by a high degree of social capital, consisting of norms of reciprocity and cooperation, and attitudes of social trust and respect (Brown and Ashman 1996). Because Tong Tasae and Laem Makham villagers reside in a remote rural area where it is difficult to seek and get external support, villagers were obliged to exist with a high degree of autonomy that supported the development of strong social capital, based on trust and reciprocity that facilitated cooperation between villagers (Pretty and Ward 2001). High social capital can promote more effective cooperation in social problem solving (Brown and Ashman 1996). Two examples demonstrate the importance of social capital in the CF villages, First, when the villages were faced with severe mangrove degradation, the community members cooperated in the mangrove conservation and management activities to protect the forest while responding to community needs. Second, in Laem Makham, the assassination of the village leader did not act as a deterrent to future collective action. Rather, the mutual trust engendered by community members maintained community resilience-resistance to change from their collective pursuit - in the face of a highmagnitude stress. Thus, social capital was a central feature of collective action to claim rights to the mangrove resource (Uphoff and Wijayaratna 2000, Pretty and Ward 2001, Gibson et al. 2005). It is very important to understand, however, that villages lacking a sufficient degree of social capital may not be able to overcome the transaction costs associated with institution building over a declining resource.

\section{Local leadership and conflict resolution}

Perhaps the most important feature of the communities that allowed them to act collectively in the face of conflict over the mangrove resource was village leadership, a finding that echoes previous research (Agrawal and Ostrom 2001, Agrawal 2003, Gibson et al. 2005, Johnson 2001, Pagdee et al. 2006). For example, village leaders acted as bridges between the YFA and the villagers, facilitating the positive outcomes associated with that assistance (see below).

Village leadership provided fair and low-cost conflict resolution, which is an important component of sustainable collective action (Ostrom 1990). In our study site, conflict arose early in the 
Table 7. Differences in mangrove tree density and basal area across community-managed (CF) and statemanaged (SF) mangrove forests in Trang, southern Thailand. $N=22$ plots for each forest. Statistical test results are for a $t$-test, $\uparrow$ : equal variances; $\$$ : unequal variances.

\begin{tabular}{|c|c|c|c|c|}
\hline \multirow[b]{2}{*}{ Parameter } & \multicolumn{2}{|c|}{ Landward mangrove } & \multicolumn{2}{|c|}{ Seaward mangrove } \\
\hline & Tong Tasae $(\mathrm{CF})$ & Tab Jak (SF) & Laem Makham (CF) & To Ban (SF) \\
\hline \multirow[t]{2}{*}{ Mean tree per plot ha- ${ }^{-1}$} & $1,372.7(1119.6)$ & 3,095.5 (1429.4) & $4,868.2(1561.3)$ & $5,654.5(2544.2)$ \\
\hline & \multicolumn{2}{|c|}{$d f^{\dagger}=42, t=-4.45, p<0.0001$} & \multicolumn{2}{|c|}{$d f^{\ddagger}=35, t=-1.236, p>0.05$} \\
\hline \multirow{2}{*}{$\begin{array}{l}\text { Mean plot basal area ha- }{ }^{-1} \\
\left(\mathrm{~cm}^{2}\right)\end{array}$} & $78.3(51.4)$ & $15.4(11.3)$ & $22.1(7.2)$ & $9.8(4.9)$ \\
\hline & \multicolumn{2}{|c|}{$d f^{\ddagger}=23, t=5.592, p<0.0001$} & \multicolumn{2}{|c|}{$d f^{\dagger}=42, t=6.599, p<0.0001$} \\
\hline
\end{tabular}

history of CF formation between the traditional users of the mangrove (villagers) and the external entities of mangrove charcoal concessionaires. In Laem Makham, serious conflict arose over resource access, leading to the assassination of the village leader. This potentially volatile conflict was addressed first by the district governor's support of village forest management and boundary delineation, and subsequently through a meeting where the RFD formally declared the forest as a CF. In Tong Tasae, conflict between the village and outsiders was also solved through a meeting coordinated by the RFD. Thus, members of Laem Makham had access to a conflict-resolution mechanism to solve a potentially debilitating conflict with outside interests. However, this access was not necessarily low cost: one village member lost his life and meetings only occurred after significant effort on the part of the communities. The adjudication process had not been established to resolve these conflicts.

Internal conflicts that arose within Laem Makham and Tong Tasae communities were also resolved by leaders. During the early stages of $\mathrm{CF}$ establishment, small conflicts among CFUGs involved in management practices were brought up for discussion in CFUG meetings. Leaders acted as mediators to reconcile the disputes among CFUGs. Moreover, leaders functioned in internal conflict resolution by establishing dialogues with nonCFUG members to explain the aims of the CF as well as to apply social sanctions to rule breakers. Subsequently, their actions resulted in eliminating possible conflicts, particularly related to mangrove logging in the $\mathrm{CF}$ area, between $\mathrm{CFUG}$ and nonCFUG members.

\section{External assistance}

Researchers have underlined the important roles that NGOs play in support of community management, especially in advocating villagers to undertake activities that demonstrate their power in the form of group action, transmitting information about community rights to villagers, and encouraging them to demand their rights and coordinate with concerned government organizations and other stakeholders (Sudara 1999, Brown and Ashman 1996, Johnson 2001, Johnson and Forsyth 2002, Pagdee et al. 2006). The YFA played an important role in the empowerment of Tong Tasae and Laem Makham in the face of substantial conflict with an external group and, in the case of Tong Tasae, neglect from the RFD. The support from the YFA to both villages in the form of capacity and awareness building and negotiation with the RFD bridged the wide gaps that existed between the villages and other stakeholders. Before the arrival of the YFA, citizens of Tong Tasae and Laem Makham were generally unaware about the mechanisms of how to interact with the RFD or gain rights over their mangrove forests, because of reduced information availability to "remote and 
Fig. 2. The diameter-at-breast-height (dbh) class distribution of the tree communities in community- and state-managed mangrove forests in Trang, southern Thailand.

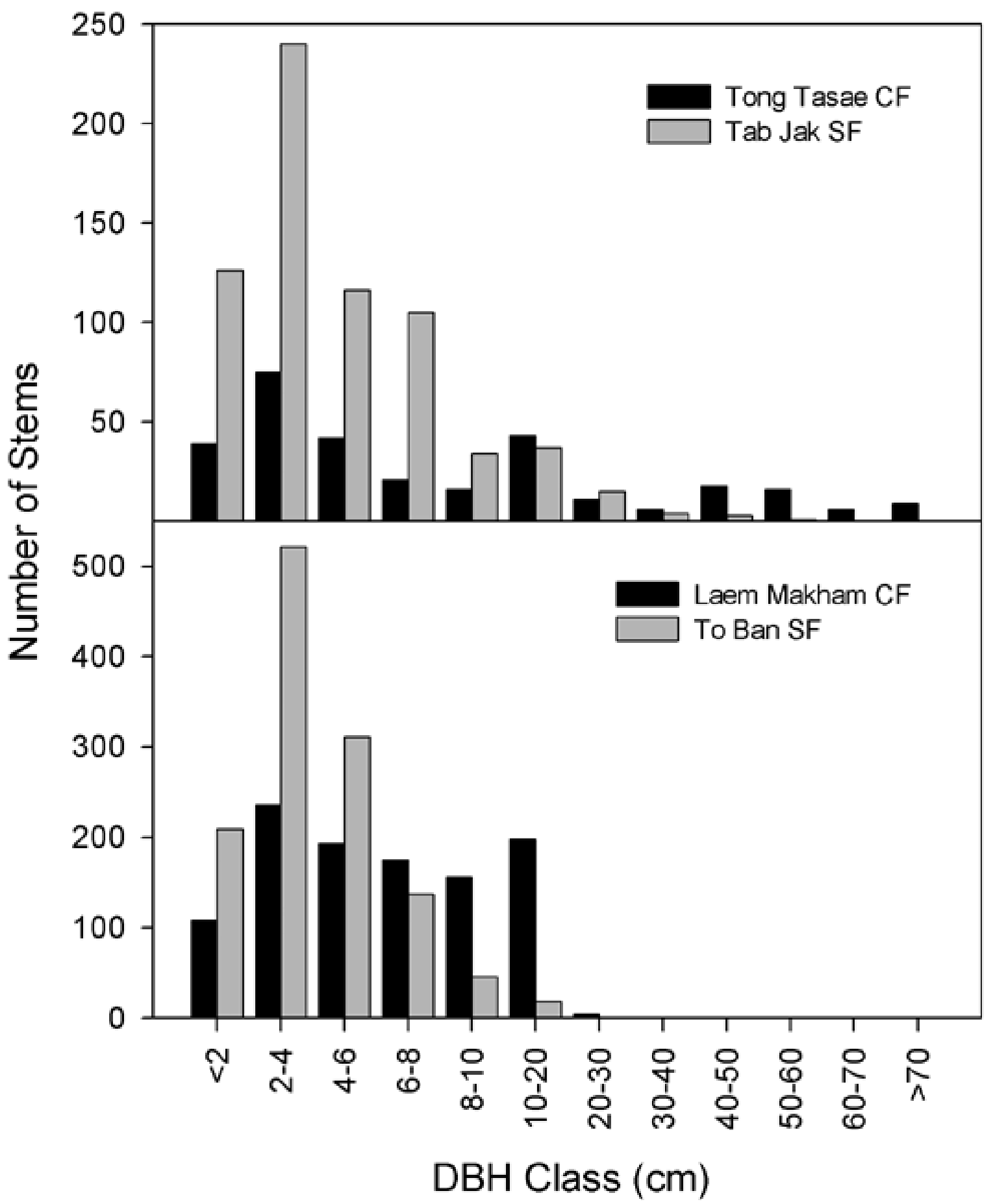


Fig. 3. The population diameter-at-breast-height (dbh) class distribution of important mangrove tree species in community- and state-managed mangrove forests in Trang, southern Thailand.

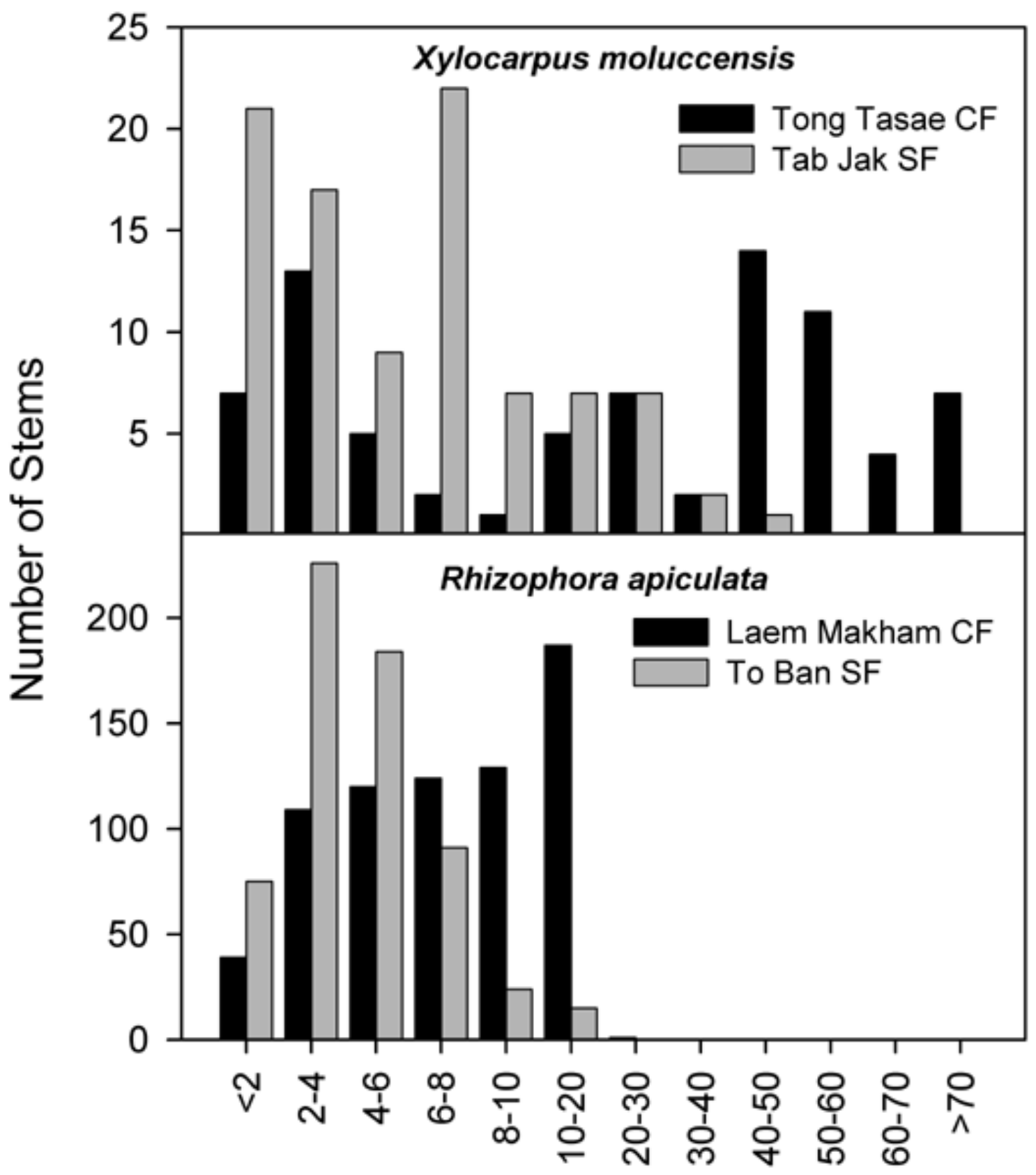

DBH Class (cm) 
Fig. 4. Tree height-class distributions in community-and state-managed mangrove forests in Trang, southern Thailand.

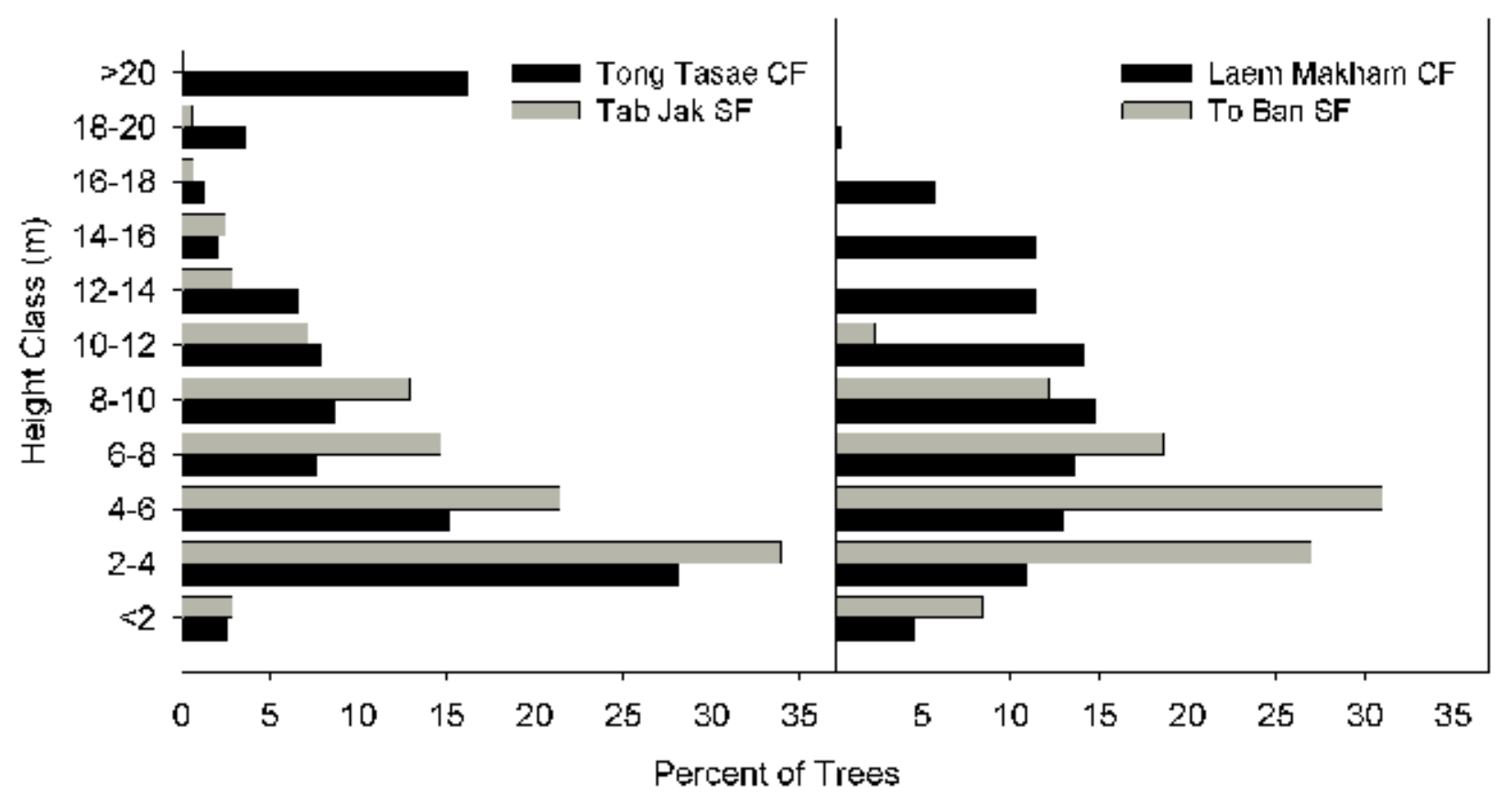

rural" villages such as theirs. The YFA, therefore, acted as a crucial source of information and training that, coupled with the experience that YFA possessed in dealing with entities like the RFD, provided the necessary facilitation for the villages to gain rights over their forests. This also occurred, of course, because of the high level of trust that was built between the YFA and the villages, which served as the foundation for higher-level empowering activities.

\section{CONCLUSION}

This study is the first to quantitatively demonstrate that mangrove forests of Thailand can be managed and conserved by local communities. Moreover, the condition of community-managed mangrove forests was superior to that managed by the state. Because there is a dearth of research on communitybased mangrove management in Asia, this study has regional implications for mangrove conservation.
Establishment of a successful community mangrove forest in the face of conflict with powerful outside interests was a major achievement in Trang, and future research should be directed to clarify how, when, and where community management is a viable alternative to state-run mangrove management.

Since the 1980s, extensive research on collectiveaction solutions to common-pool resource dilemmas supports the hypothesis that certain contextual ("facilitating") conditions are crucial to the emergence of sustainable collective action over common-pool resources (Agrawal 2003). We have argued that the successful establishment of CFs in Tong Tasae and Laem Makham villages was the result of several contextual factors, including the necessity of the resource for livelihoods, local village autonomy, the establishment of clear boundaries to exclude non-community members and clarify costs, effective monitoring and graduated sanctions, a high degree of social capital, effective leadership and low-cost conflict 
resolution, and the support of an external entity to improve information flow to the communities and to bridge gaps with unaccommodating state agencies.

In addition to the community-level factors listed above, the wider political arena may affect the success of community-based mangrove management in southern Thailand. For example, decentralization or devolution of decision making to local levels creates space for locally crafted solutions for management of resources (Edmunds and Wollenberg 2003, Webb and Shivakoti 2008). In Thailand, the Constitution of 1997 gives local people the right to protect and conserve natural resources in their locality. Based on that right, local communities can operate $\mathrm{CFs}$, and the clear articulation of local rights has reduced conflicts like the ones we found in our study sites. Thus, the larger political trend in Thailand may be improving the possibility for successful community-based mangrove management.

The obvious question that follows this research is that, despite similar contextual situations, why did Tong Tasae and Laem Makham exhibit these contextual facilitating factors, and why not Tab Jak and To Ban? The broader question of what underlies the presence or absence of facilitating conditions in rural, resource-dependent communities has not been given sufficient theoretical or empirical treatment. One hypothesis we can generate here is that the presence of collective-action-facilitating conditions may be influenced by the presence of endowments or "assets," which are central factors in determining livelihood stability and outcomes (Carney 1998; A. Agrawal, personal commmunication). Examining the links between livelihood assets and the presence of collective-action-facilitating conditions could be a direction for future research.

Responses to this article can be read online at: http://www.ecologyandsociety.org/voll3/iss2/art27/responses/

\section{Acknowledgments:}

The authors thank Rajamangala University of Technology Srivijaya for the financial support for this research. We also thank A. Agrawal and E. Ostrom for input on an earlier version of the manuscript.

\section{LITERATURE CITED}

Adeel, Z., and R. Pomeroy. 2002. Assessment and management of mangrove ecosystems in developing countries. Trees 16(2-3):235-238.

Agrawal, A. 2003. Sustainable governance of common-pool resources: context, methods, politics. Annual Review of Anthropology 32:243-262.

Agrawal, A., and C. C. Gibson. 1999. Enchantment and disenchantment: the role of community in natural resource conservation. World Development 27(4):629-649.

Agrawal, A., and E. Ostrom. 2001. Collective action, property rights, and decentralization in resource use in India and Nepal. Politics and Society 29(4):485-514.

Aksornkoae, S. 1993. Ecology and management of mangroves. International Union for the Conservation of Nature and Natural Resources, Bangkok, Thailand.

Aksornkoae, S. 2004. Sustainable use and conservation of mangrove forest resources with emphasis on policy and management practices in Thailand. Pages 149-160 in M. Vannucci, editor. Mangrove management and conservation: present and future. United Nations University Press, New York, New York, USA.

Aksornkoae, S., G. S. Maxwell, S. Havanon, and S. Panichsuko. 1992. Plants in mangroves. Chalongrat Co. Ltd., Bangkok, Thailand.

Alcala, A. C. 1998. Community-based coastal resource management in the Philippines: a case study. Ocean and Coastal Management 38:179_ 186.

Alongi, D. M. 2002. Present state and future of the world's mangrove forests. Environmental Conservation 29:331-349.

Ashton, E. C., and D. J. Macintosh. 2002. Preliminary assessment of the plant diversity and community ecology of Sematan mangrove forest, Sarawak, Malaysia. Forest Ecology and Management 166:111-129.

Bardhan, P. 1993. Analytics of the institutions of informal cooperation in rural development. World Development 21(4):633-639. 
Bray, J. R., and J. T. Curtis. 1957. An ordination of the upland forest communities of southern Wisconsin. Ecological Monographs 27(4):325349.

Brown, D. L., and D. Ashman. 1996. Participation, social capital, and interaction problem solving: African and Asian cases. World Development 24 (9):1467-1479.

Carney, D. 1998. Sustainable rural livelihoods: what contribution can we make? Department for International Development, London, UK.

Clark, K. R., and R. M. Warwick. 1994. Changes in marine communities: an approach to statistical analysis and interpretation. PRIMER-E Ltd, Plymouth, UK.

Dietz, T., E. Ostrom, and P. Stern. 2003. The struggle to govern the commons. Science $\mathbf{3 0 2}$ (12):1907-1912.

Duke, N. C., M. C. Ball, and J. C. Ellison. 1998. Factors influencing biodiversity and distributional gradients in mangroves. Global Ecology and Biogeography Letters 7(1):21-47.

Edmunds, D., and E. Wollenberg. 2003. Local forest management: the impacts of devolution policies. Earthscan Publications Ltd., London, UK.

English, S., C. Wilkinson, and V. Baker. 1994. Survey manual for tropical marine resources. Australian Institute of Marine Science, Townsville, Australia.

Galli, D. 2007. "Tragedy in common" or "mutual success": assessment of community-based forest management in western Thailand. Thesis, Asian Institute of Technology, Bangkok, Thailand.

Ganjanapan, A. 2003. Complexity of rights and legal pluralism in participatory watershed development in Thailand. Pages 207-212 in X. Jianchu and S. Mikesell, editors. Landscapes of diversity: indigenous knowledge, sustainable livelihoods and resource governance in montane mainland Southeast Asia. Proceedings of the III Symposium on MMSEA (Lijiang 2002). Yunnan Science and Technology Press, Kunming, People's Republic of China.

Gautam, A. P., and G. P. Shivakoti. 2005. Conditions for successful local collective action in forestry: some evidence from the hills of Nepal. Society and Natural Resources 18: 153-171.

Gautam, A. P., E. L. Webb, and A. Eiumnoh. 2002. GIS assessment of land use/land cover changes associated with community forestry implementation in the Middle Hills of Nepal. Mountain Research and Development 22:63-39.

Gibson, C. C., E. Ostrom, and M. A. McKean. 2000. Forests, people and governance: some initial theoretical lessons. Pages 227-242 in C. C. Gibson, M. A. McKean, and E. Ostrom, editors. People and forests. The MIT Press, Cambridge, Massachusetts, USA.

Gibson, C. C., J. T. Williams, and E. Ostrom. 2005. Local enforcement and better forests. World Development 33(2):273-284.

Hanna, S., and M. Munasinghe. 1995. Property rights in a social and ecological context: case studies and design applications. Beijer International Institute, Stockholm, Sweden.

Heltberg, R. 2001. Determinants and impact of local institutions for common resource management. Environment and Development Economics 6:183208.

Hill, M. O. 1973. Diversity and evenness: a unifying notation and its consequences. Ecology 54:427432.

Johnson, C. 2001. Community formation and fisheries conservation in southern Thailand. Development and Change 23:951-974.

Johnson, C., and T. Forsyth. 2002. In the eyes of the state: "negotiating a rights-based approach" to forest conservation in Thailand. World Development 30(9):1591-1605.

Kabir, M. E., and E. L. Webb. 2006. Saving a forest: the composition and structure of a deciduous forest under community management in northeast Thailand. Natural History Bulletin of the Siam Society 54:63-84.

Kairo, J. G., F. Dahdouh-Guebas, P. O. Gwada, C. Ochieng, and N. Koedom. 2002. Regeneration status of mangrove forests in Mida Creek, Kenya: a compromised or secured future? Ambio 3:562568. 
Kathiresan, K., and N. Rajendran. 2005. Coastal mangrove forests mitigated tsunami. Estuarine Coastal and Shelf Science 65(3):601-606.

Katon, B. M., R. S. Pomeroy, L. R. Garces, and M. W. Ring. 2000. Rehabilitating the mangrove resources of Cogtong Bay, Philippines: a comanagement perspective. Coastal Management 28:29-37.

Kijtewachakul, N., G. P. Shivakoti, and E. L Webb. 2004. Forest health, collective behaviors, and management. Environmental Management 33 (5):620-636.

Macintosh, D. J., E. C. Aston, and S. Havanon. 2002. Mangrove rehabilitation and intertidal biodiversity: a study in the Ranong mangrove ecosystem, Thailand. Estuarine, Coastal and Shelf Science 55(3):331-345.

Margalef, R. 1958. Information theory in ecology. General Systematics 3:36-71.

Nagelkerken, I., G. van der Velde, M. W. Gorissen, G. J. Meijer, T. Van't Hof, and C. den Hartog. 2000. Importance of mangroves, seagrass beds and the shallow coral reef as nursery for important coral reef fishes, using a visual census technique. Estuarine, Coastal and Shelf Science $\mathbf{5}$ (1):31-44.

Ostrom, E. 1990. Governing the commons: the evaluation of institutions for collective action. Cambridge University Press, New York, New York, USA.

Othman, M. A. 1994. Value of mangroves in coastal protection. Hydrobiologia 285(1-3):277282.

Pagdee, A., Y. Kim, and P. J. Daugherty. 2006. What makes community forest management successful: a meta-study from community forests throughout the world. Society and Natural Resources 19:33-52.

Pielou, E. C. 1975. Ecological diversity. John Wiley, New York, New York, USA.

Plathong, J., and N. Sitthirach. 1997. Traditional and current uses of mangrove forests in southern Thailand. Wetlands International-Thailand Programme Publication No. 3. Wetlands International-Thailand Programme, Hat Yai, Thailand.
Pomeroy, R. S. 1995. Community-based and comanagement institutions for sustainable coastal fisheries management in Southeast Asia. Ocean and Coastal Management 27(3):143-162.

Pomeroy, R. S., and M. B. Carlos. 1997. Community-based coastal resource management in the Philippines: a review and evaluation of programs and projects, 1984-1994. Marine Policy 21(5):445-464.

Pretty, J. P., and H. Ward. 2001. Social capital and the environment. World Development 29(2):209227.

Rittibhonbhun, N., P. Chansanoh, S. Tongrak, and R. Suwannatchote. 1993. Community-based mangrove rehabilitation and management: a case study in Sikao District, Trang Province, Southern Thailand. Regional Development Dialogue 14:111122.

Sathirathai, S. 1997. Economic valuation of mangroves and the roles of local communities in the conservation of natural resources: case study of Surat Thani, south of Thailand. International Development Research Centre, Ottawa, Ontario, Canada. [online] URL: http://www.idrc.ca/en/ev-84 37-201-1-DO TOPIC.html.

Sathirathai, S., and E. B. Barbier. 2001. Valuing mangrove conservation in Southern Thailand. Contemporary Economic Policy 19(2):109-122.

Shannon, C. E., and W. Weaver. 1949. The mathematical theory of communication. University of Illinois Press, Urbana, Illinois, USA.

Smith, A. H., and F. Berkes. 1993. Communitybased use of mangrove resources in St. Lucia. International Journal of Environmental Studies 43: $123-131$.

Smith, T. J. III 1992. Forest structure. Pages 101136 in A. I. Robertson and D. M. Alongi, editors. Tropical mangrove ecosystems. Coastal and Estuarine Studies 41. American Geophysical Union, Washington, D.C., USA.

Sudara, S. 1999. Who and what is to be involved in successful coastal zone management: a Thailand example. Ocean and Coastal Management 42 (1):39-47.

Soontornwong, S. 2006. Improving livelihood 
through CBNRM: a case of self-organization in community mangrove management in Thailand. Pages 182-199 in S. Mahanty, J. Fox, M. Nurse, P. Stephen, and L. McLees, editors. Hanging in the balance: equity in community-based natural resource management in Asia. East-West Center, Honolulu, Hawaii, USA.

Tabucanon, M. S. 1991. State of coastal resource management strategy in Thailand. Marine Pollution Bulletin 23:579-586.

Tomlinson, P. B. 1986. The botany of mangroves. Cambridge University Press, Cambridge, UK.

Uphoff, N., and C. M. Wijayaratna. 2000. Demonstrated benefits from social capital: the productivity of farmer organizations in Gal Oya, Sri Lanka. World Development 28 (11):1875-1890.

Valiela, I., J. L. Bowen, and J. K. York. 2001. Mangrove forests: one of the world's threatened major tropical environments. Bioscience $\mathbf{5 1}$ (10):807-815.

Walters, B. B. 2000. Local mangrove planting in the Philippines: are fisherfolk and fishpond owners effective restoration? Restoration Ecology 8 (3):237-246.

Walters, B. B. 2003. People and mangroves in the Philippines: fifty years of coastal environmental change. Environmental Conservation 30(2):293303.

Walters, B. B. 2004. Local management of mangrove forests in the Philippines: successful conservation or efficient resource exploitation? Human Ecology 32(2):177-195.

Walters, B. B. 2005. Patterns of local wood use and cutting of Philippine mangrove forests. Economic Botany 59(1):66-76.

Webb, E. L. 2008. Forest policy as a changing context in Asia. Pages 21-43 in E. L. Webb and G. P. Shivakoti, editors. Decentralization, forests and rural communities: policy outcomes in south and southeast Asia. Sage Press, New Dehli, India.

Webb, E. L., and G. P. Shivakoti, editors. 2008. Decentralization, forests and rural communities: policy outcomes in South and Southeast Asia. Sage Press, New Dehli, India.
Wilkie, M. L., and S. Fortuna. 2003. Status and trends in mangrove area extent worldwide. Forest Resources Assessment Working Paper-63. Food and Agriculture Organization of the United Nations, Rome, Italy. 